\title{
Electrochemical Impedance and Modelling Studies of the Corrosion of Three Commercial Stainless Steels in Molten Carbonate
}

\author{
C. S. Ni and L. Y. Lu \\ State Key Laboratory for Corrosion and Protection, Institute of Metal Research, Chinese Academy of Sciences, Shenyang 110016, China \\ Correspondence should be addressed to C. S. Ni; nichengsheg@gmail.com
}

Received 2 June 2014; Revised 22 October 2014; Accepted 23 October 2014; Published 6 November 2014

Academic Editor: Flavio Deflorian

Copyright (C) 2014 C. S. Ni and L. Y. Lu. This is an open access article distributed under the Creative Commons Attribution License, which permits unrestricted use, distribution, and reproduction in any medium, provided the original work is properly cited.

\begin{abstract}
The corrosion induced by molten carbonates on the metallic structure materials is a problem constraining the life span of molten carbonate fuel cell (MCFC) at elevated temperatures. The reaction between the outgrowing oxide scale and lithium carbonate in the electrolyte is generally a slow process and very important to the passivation behaviour of the underlying steel. The corrosion behaviour of three commercial alloys (P92, SS304, and SS310) with different $\mathrm{Cr}$ contents in molten $(0.62 \mathrm{Li}, 0.38 \mathrm{~K})_{2} \mathrm{CO}_{3}$ at $650^{\circ} \mathrm{C}$ was monitored by electrochemical impedance spectroscopy (EIS) for 120 hours to investigate the lithiation process. With SEM images and extensive XRD analysis of the oxides, equivalent circuits were proposed to interpret the impedance data and explain the corrosion behaviour of the three alloys at different stage with respect to lithiation process.
\end{abstract}

\section{Introduction}

Cathode dissolution and metallic corrosion in contact with molten carbonate are two crucial problems limiting the life span of a molten carbonate fuel cell (MCFC). The metallic structure materials subjected to corrosion are separator plates and the current collectors. Aluminium-containing materials are extremely corrosion resistant in molten carbonate [13 ] and can be used for wet-sealing area, but they are too electrically resistive to be used for current collecting areas. A balance between the corrosion resistance and oxide scale resistivity for materials of bipolar plates at the working temperature of $650^{\circ} \mathrm{C}$ should be struck in order to achieve a long life span of 40000 hours with high productivity [4-6]. Biedenkopf et al. [4] reported that the electrical conductivity was limited by the inner, chromium-containing oxide of a multilayered corrosion scale, and chromium-rich alloys with a $\mathrm{Cr}$ content higher than $20 \mathrm{wt} . \%$ showed extremely high ohmic resistance of the Cr-containing corrosion scale, in contrast to the formation of highly conductive mixed spinel layers on steels with $\mathrm{Cr}$ content less than $20 \mathrm{wt}$.\%. In addition, Spiegel et al. $[7,8]$ studied the corrosion of iron-based alloy and high alloys in eutectic $\mathrm{Li}_{2} \mathrm{CO}_{3}-\mathrm{K}_{2} \mathrm{CO}_{3}$ melt and pointed out that the chromium content of the alloy should not exceed $12-15$ wt.\% to prevent the loss of chromium through the formation of dissolvable potassium chromate.

The corrosion caused by molten salt is an electrochemical process in nature, so electrochemical techniques can be applied to study the mechanism [9-16]. Electrochemical impedance spectroscopy (EIS) is a technique that has proven to be effective in investigating reaction mechanisms and kinetics in hot corrosion induced by molten carbonate. The impedance response of pure $\mathrm{Ni}, \mathrm{FeAl}$ (Fe-24.4Al-0.12B wt.\%), CuAl (Cu-15Alwt.\%), NiTi (Ni-10, 15Tiwt.\%), NiCo (Ni50Co wt.\%), and AISI 310 stainless steel (Fe-25Cr-20Ni wt.\%) after different immersion times in molten carbonate at $650^{\circ} \mathrm{C}$ was monitored and corresponding models were proposed to specify the corrosion mechanism [9-11, 17, 18]. Electrochemical impedance was also used to assess the corrosion resistance of different chromium content alloys against molten carbonate after a given immersion period [12, 13]. Frangini [14] compared the corrosion kinetics of 310S stainless steel in molten carbonates obtained with impedance spectra and linear polarization and concluded that the presence of diffusion impedance terms and formation of resistive surface films coupled with lithiation process might result in unreliable 
resistance values obtained with the linear polarization. Zhu et al. [15] found that the corrosion rates estimated from the two electrochemical techniques concurred only at the initial period of immersion before the formation of protective scales. The significant perturbations of the current in Tafel polarization on the scale bring error to the calculation of corrosion rate, while EIS is a good tool in studying the properties of scales by applying small perturbation $(<10 \mathrm{mV})$ to the system.

The lithiation process is one of the reasons for the electrolyte loss during the operating time of an MCFC $[19,20]$ and, more importantly, this process will change the properties of the scales of stainless steel under thin film of molten carbonate [21-24]. The corrosion of stainless steel in the cathode compartment or the immersion corrosion will last longer times than thin-film corrosion, so longer testing would be required to study the whole process. The surrounding melt in dip-melt test will provide sufficient lithium and potassium to react with the oxide scale. Unlike the general short-term or instant testing, this report serves to study the corrosion process of three commercial alloys with different chromium content for extended times by impedance techniques in terms of monitoring the outgrowth of oxide scale and the lithiation process. To be specific, the corrosion process of three commercial stainless steels, P92, SS304, and SS310 when immersed fully in molten $(0.62 \mathrm{Li}, 0.38 \mathrm{~K})_{2} \mathrm{CO}_{3}$ at $650^{\circ} \mathrm{C}$ was investigated using EIS technique. This technique provides a real-time monitoring process of the experiment without disturbing the thermodynamic system; so many measurements can be taken at different times to establish the corrosion mechanism.

\section{Experimental}

The powers of anhydrous carbonates, $62 \% \mathrm{Li}_{2} \mathrm{CO}_{3}$ and $38 \%$ $\mathrm{K}_{2} \mathrm{CO}_{3}$ in mole fraction, were weighed and mixed in an alumina crucible, which was then placed in a cylindrical furnace to be baked at $350^{\circ} \mathrm{C}$ for $24 \mathrm{~h}$ in order to purge the residual moisture. And then the furnace was heated to $650^{\circ} \mathrm{C}$ at a ramp of $3^{\circ} \mathrm{C} / \mathrm{min}$. Flat rectangular specimens were cut from bulk alloys and ground to 800 emery paper. The compositions of the three alloys were shown in Table 1.

A two-electrode system was used for the impedance measurements, where the working electrode was identical to reference electrode and auxiliary electrode. The reference probe is connected to the probe of auxiliary electrode. The impedance measurement is assumed to be ac OCV and the impedance for each sample should be the final impedance divided by a factor of two. A detailed experimental setup can be found in [2]. Two specimens of the same stainless steel were imbedded in an alumina tube and sealed with high temperature cement after a Fe-Cr lead wire had been spot-welded on the fringe of each specimen. The working surface of each electrode was $10 \mathrm{~mm} \times 8 \mathrm{~mm}$. For each alloy, the electrochemical measurements are reproduced twice with the same materials and working conditions to confirm the validity of the modeling.

Electrochemical-impedance measurements up to $120 \mathrm{~h}$ were performed at open-circuit potential in air between 0.01
TABLE 1: The compositions of the three commercial stainless steels.

\begin{tabular}{lc}
\hline Stainless steel & Composition (wt.\%) \\
\hline P92 & Fe-9.0Cr-1.8W-0.5Mn-0.4Mo-0.11Si-0.2V \\
SS304 & Fe-19.3Cr-9.4Ni-2.0Mn-0.9Si \\
SS310 & Fe-26.4Cr-18.5Ni-1.4Mn \\
\hline
\end{tabular}

and $1 \times 10^{5} \mathrm{~Hz}$ with a M398 impedance system, composed of a Princeton applied research (PAR) 5210 lock-in amplifier and a PAR 263 potentiostat interfaced through an IEEE 488 bus to a compatible computer. A fast Fourier transform (FFT) technique was employed for frequencies from 0.01 to $1.13 \mathrm{~Hz}$ to increase measurement speed and lower the degree of perturbation to the cell. The amplitude of input sine signal was $10 \mathrm{mV}$. A commercial software (ZSimpWin) developed by PAR was used to fit the impedance spectra using complex nonlinear least squares (CNLS) method.

The corroded samples were examined by X-ray diffraction (XRD) and scanning electron microscopy (SEM) coupled with an energy-dispersive X-ray (EDX) microanalysis system. The XRD patterns of the corrosion products at inner layer were obtained by scrubbing off the surface product layer with sand paper.

\section{Results}

3.1. EIS Measurement. The corresponding Bode phase plots, as shown in Figure 1, show two time constants during the initial 48 hours but one time constant at high frequency at $72 \mathrm{~h}$ and $120 \mathrm{~h}$. The characteristic frequency of the highfrequency loop is at $1000 \mathrm{~Hz}$ through the whole process. The impedance moduli begin to decrease, after the disappearance of time constant at frequency of $0.1 \mathrm{~Hz}$, in contrast to the relatively stable value during the first 48 hours.

Over the whole corrosion process, the Bode plots of SS304 consist of only one time constant with a characteristic frequency of $1000 \mathrm{~Hz}$ and a line at low-frequency range, as shown in Figure 2. It is noteworthy that the phase angle of the low frequency angle of the Bode plots decreases when the corrosion proceeded. The moduli of the impedance at low frequency almost do not change with time.

Figure 3 is the Bode plots of SS310 in molten carbonate at different times. When the immersion time is prior to 12 hours, two time constants, one at $1000 \mathrm{~Hz}$ and one at $0.5 \mathrm{~Hz}$, can be identified. From $12 \mathrm{~h}$ onward to the end of the test, a line at low frequency in addition to the two time constants can be found in the impedance spectra.

3.2. Scale Morphology and Phase Analysis. A multilayer scale is formed on P92 after $120 \mathrm{~h}$ immersion in molten carbonate at $650^{\circ} \mathrm{C}$. The thickness of the scale is $80 \mu \mathrm{m}$ and a darker layer in contact with the indented steel substrate as shown in Figure 4(a). An enlarged view of the inner layer (Figure 4(b)) indicates that this layer is more porous than the out layer, and some bright $\mathrm{W}$ or Mo particles are scattering in the oxide. Parezanović et al. [25] found that Mo preferred to stay at the metal side in solid solution with spinel oxides 

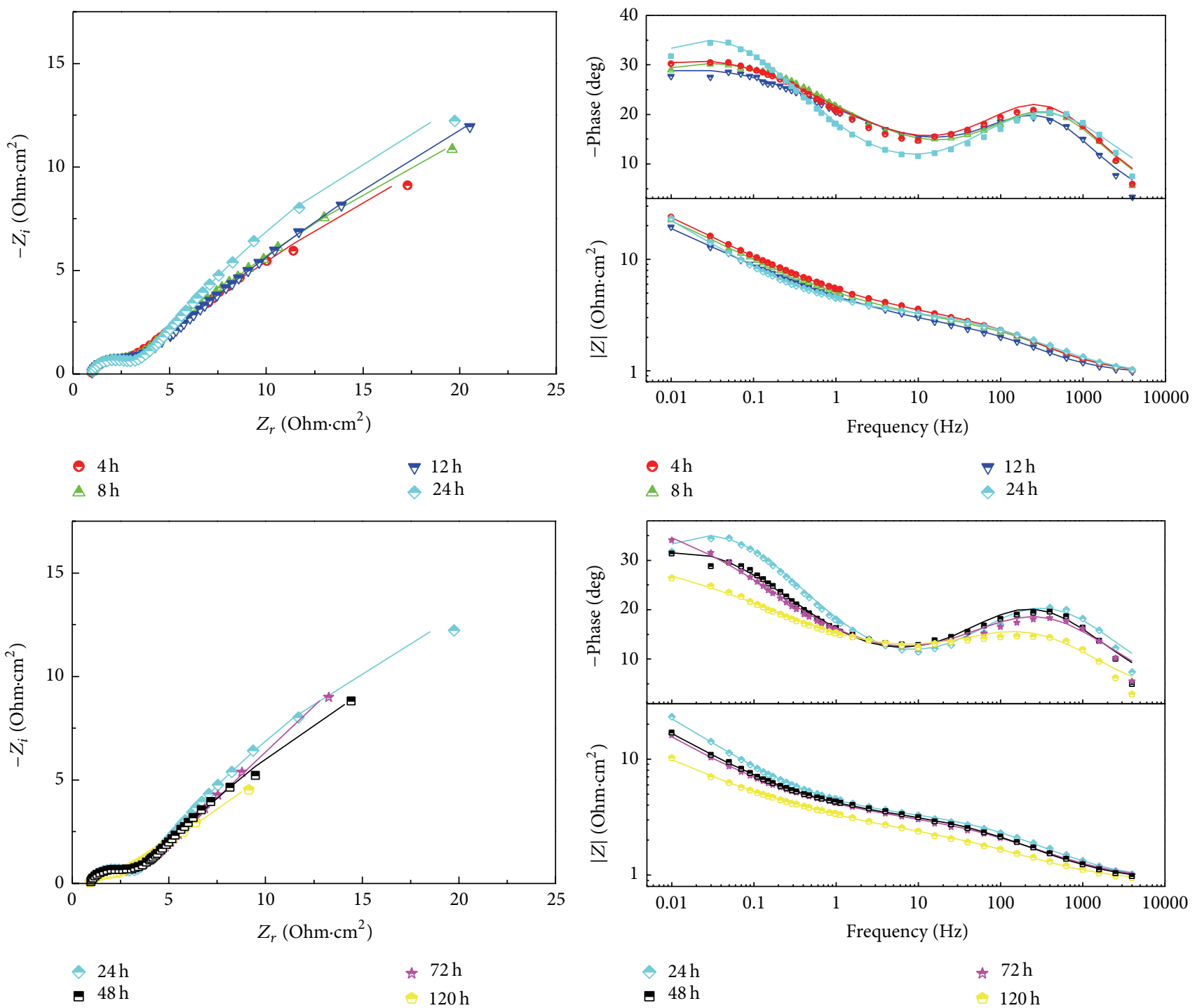

Figure 1: Nyquist and Bode plots of P92 in molten carbonate at $650^{\circ} \mathrm{C}$ in air. Scattered points are measured data and lines are simulated data.

and tungsten precipitates also situated on the matrix-scale interface in our case. The EDX line plot along the scale shows that no chromium-rich scale is formed in the whole range and significant potassium can be detected in the porous scale close to the base metal. Judging from the XRD results in Figure 7(a), one can see that the outer layer was composed of $\mathrm{LiFeO}_{2}$ and $\mathrm{K}_{2} \mathrm{Fe}_{2} \mathrm{O}_{4}$ while the inner layer was composed of $\mathrm{FeO}$ and $\mathrm{FeCr}_{2} \mathrm{O}_{4}$. At the eutectic composition with $x\left(\mathrm{Li}_{2} \mathrm{CO}_{3}\right)=0.62$, the production of $\mathrm{LiFeO}_{2}$ other than $\mathrm{K}_{2} \mathrm{Fe}_{2} \mathrm{O}_{4}$ at the scale/melt interface is attributed to the lower stability of $\mathrm{Li}_{2} \mathrm{CO}_{3}$ and higher $\mathrm{Li}$ activity, even though $\mathrm{K}_{2} \mathrm{Fe}_{2} \mathrm{O}_{4}$ shows higher stability energy at $650^{\circ} \mathrm{C}$. The lithiation could happen with the transport of the $\mathrm{Li}$ ion through the $\mathrm{LiFeO}_{2}$ scale that combined with the incoming $\mathrm{Fe}^{3+}$ ion to form new ternary oxides $\mathrm{LiFeO}_{2}$. However, the potassium is less likely to diffuse through the scale owing to its large ionic radius, so the potassium containing oxides are generally at the scale/melt interface as in $\mathrm{K}_{2} \mathrm{CrO}_{4}$ [11].
According to the phase diagram of $\mathrm{Li}-\mathrm{K}-\mathrm{C}-\mathrm{Fe}$ [26], the porous $\mathrm{K}_{2} \mathrm{Fe}_{2} \mathrm{O}_{4}$ can be a result of the direct penetration of the viscous mixed carbonate into the metal/scale interface and react with newly formed $\mathrm{Fe}_{2} \mathrm{O}_{3}$ after the depletion of $\mathrm{Li}$ from the melt in this area, as is reported by Spiegel in the study of corrosion of metals underneath chlorides [27].

The scale on SS304 (Figure 5(a)) was $40 \mu \mathrm{m}$ thick and contains three layers: the $20 \mu \mathrm{m}$ outermost layer and the innermost layer are separated by a darker region in the middle. The outermost layer has even thickness in the whole range and shows a clear boundary tithe the intermediate layer. The innermost layer has a rugged surface toward the metal side and is dispersed by bright particles. The surface morphology of the scale on SS304 where the outermost layer spalled off is shown in Figure 8(a). The outermost layer is composed of compact crystals as shown in the enlarged view in Figure 8(b), whose metallic elements judged from EDX are mostly $\mathrm{Fe}$ and slight $\mathrm{Cr}$. The surface morphology of 

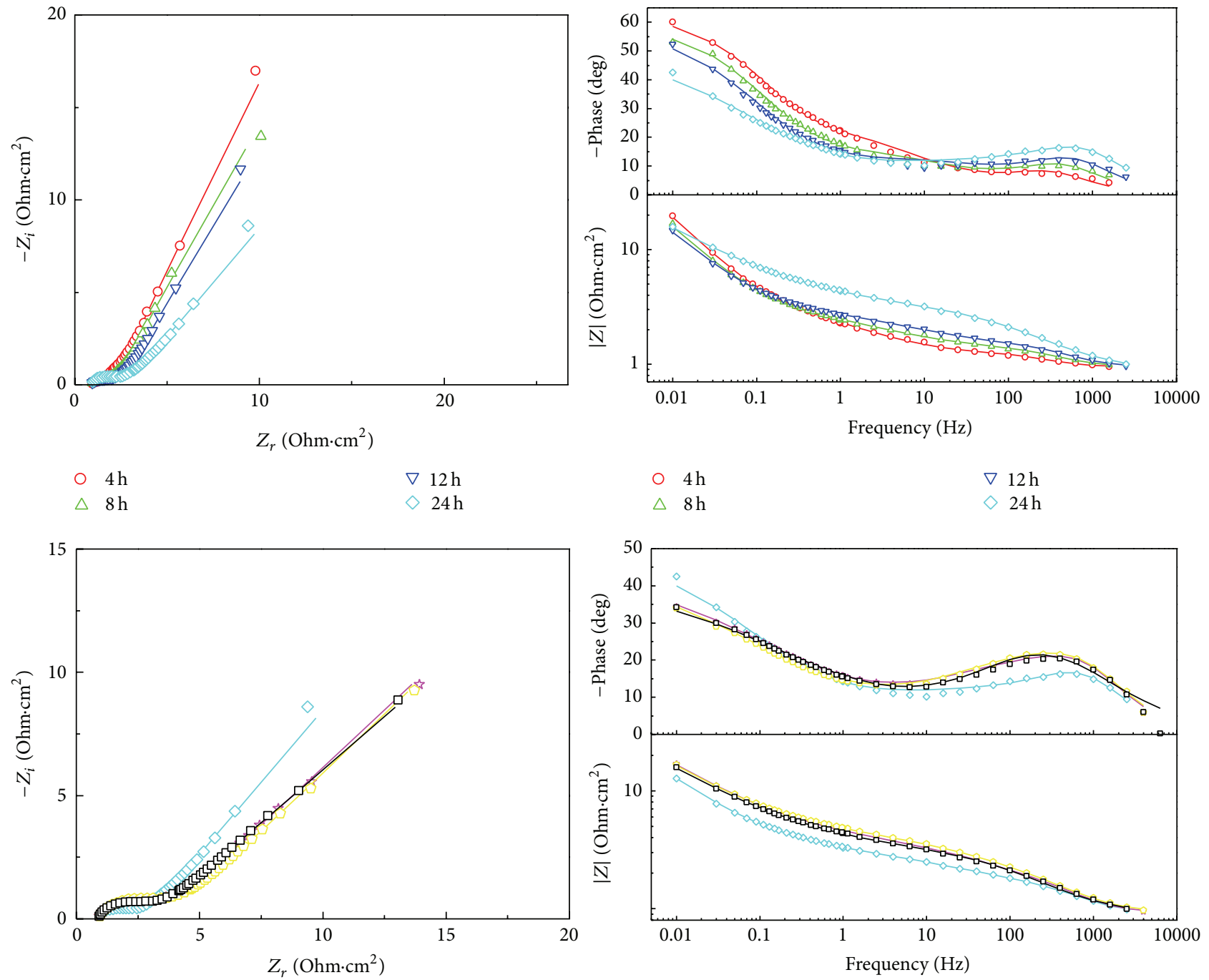
$\circ 4 \mathrm{~h}$
$\nabla 12 \mathrm{~h}$
$\triangle 8 \mathrm{~h}$
$\diamond 24 \mathrm{~h}$

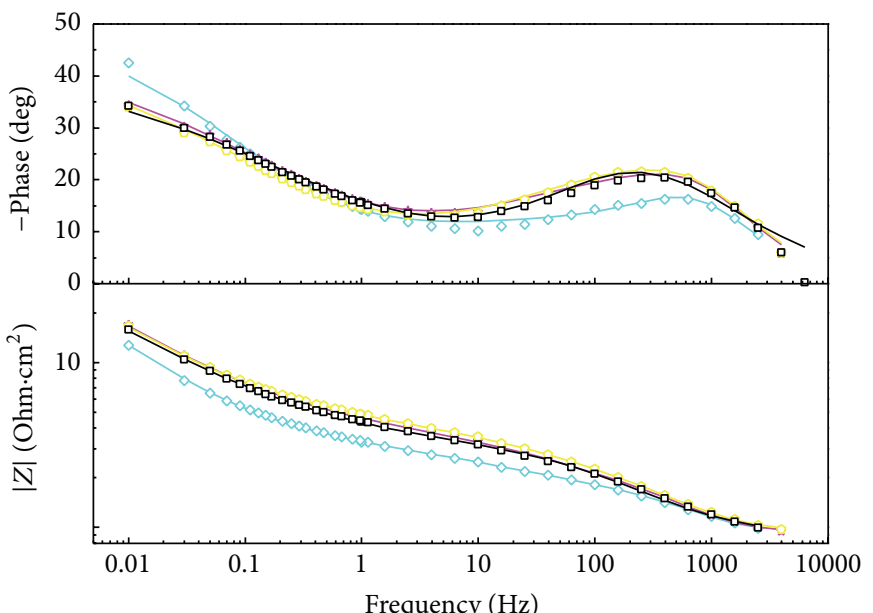

$\diamond 24 \mathrm{~h}$
$\square \quad 48 \mathrm{~h}$

\& $72 \mathrm{~h}$

$120 \mathrm{~h}$

$\diamond 24 \mathrm{~h}$
$\square \quad 48 \mathrm{~h}$

is $72 \mathrm{~h}$

$120 \mathrm{~h}$

FIGURE 2: Nyquist and Bode plots of SS304 in molten carbonate at $650^{\circ} \mathrm{C}$ in air. Scattered points are measured data and lines are simulated data.

$\mathrm{LiFeO}_{2}$ seems to be fairly dense, but the cross-sectional image indicates the existence of fissures throughout the scale. The composition of oxides on the top of intermediate layer was $67 \% \mathrm{Cr}-26 \% \mathrm{Fe}-7 \% \mathrm{Ni}$ in atomic percent. Assisted by XRD patterns in Figure 7(b), one can judge that the outer layer is composed of exclusively $\mathrm{LiFeO}_{2}$, the intermediate layer mixture is composed of $\mathrm{LiFeO}_{2}$ and $\mathrm{LiCrO}_{2}$ and $(\mathrm{Fe}, \mathrm{Ni}) \mathrm{Cr}_{2} \mathrm{O}_{4}$ and $\mathrm{Ni}$ particles, and the innermost layer is composed of mainly $(\mathrm{Fe}, \mathrm{Ni}) \mathrm{Cr}_{2} \mathrm{O}_{4}$.

A $10 \mu \mathrm{m}$ double-layered scale outgrows the 310 alloy surface after $120 \mathrm{~h}$ of corrosion, as shown in Figure 6. The continuous thin dark layer is surmounted by a bright layer containing bright particles on the surface and pore in the middle. A comparison between the XRD patterns (Figure 5(c)) of the inner layer and outer layer indicates that the outer layer was $\mathrm{LiFeO}_{2}$ and the inner layer is $\mathrm{LiCrO}_{2}$ because the peaks of
$\mathrm{LiFeO}_{2}$ stun much when the specimen is scrubbed with sand paper to remove the top layer. With EDX data, the especially bright particles on the surface containing 3.5 at.\% $\mathrm{Mn}$ are thought to be $\mathrm{Mn}$ dissolved $\mathrm{LiFeO}_{2}$ [8].

3.3. Impedance Models. The impedance spectra of P92 at the initial stage showed clearly the features of a porous-scale covered electrode. Therefore, the impedance model for the corrosion of P92 at this stage may be described by circuit of Figure 9(a), where $R_{e}$ represents the electrolyte resistance, $C_{\mathrm{dl}}$ and $C_{f}$ represent the double-layer capacitance and oxide capacitance, respectively, $R_{\mathrm{ct}}$ and $R_{f}$ represent the chargetransfer resistance and oxide resistance, respectively, and $A_{d}$ represents the diffusion-induced Warburg resistance. Taking into account the dispersion effect, a constant phase angle 

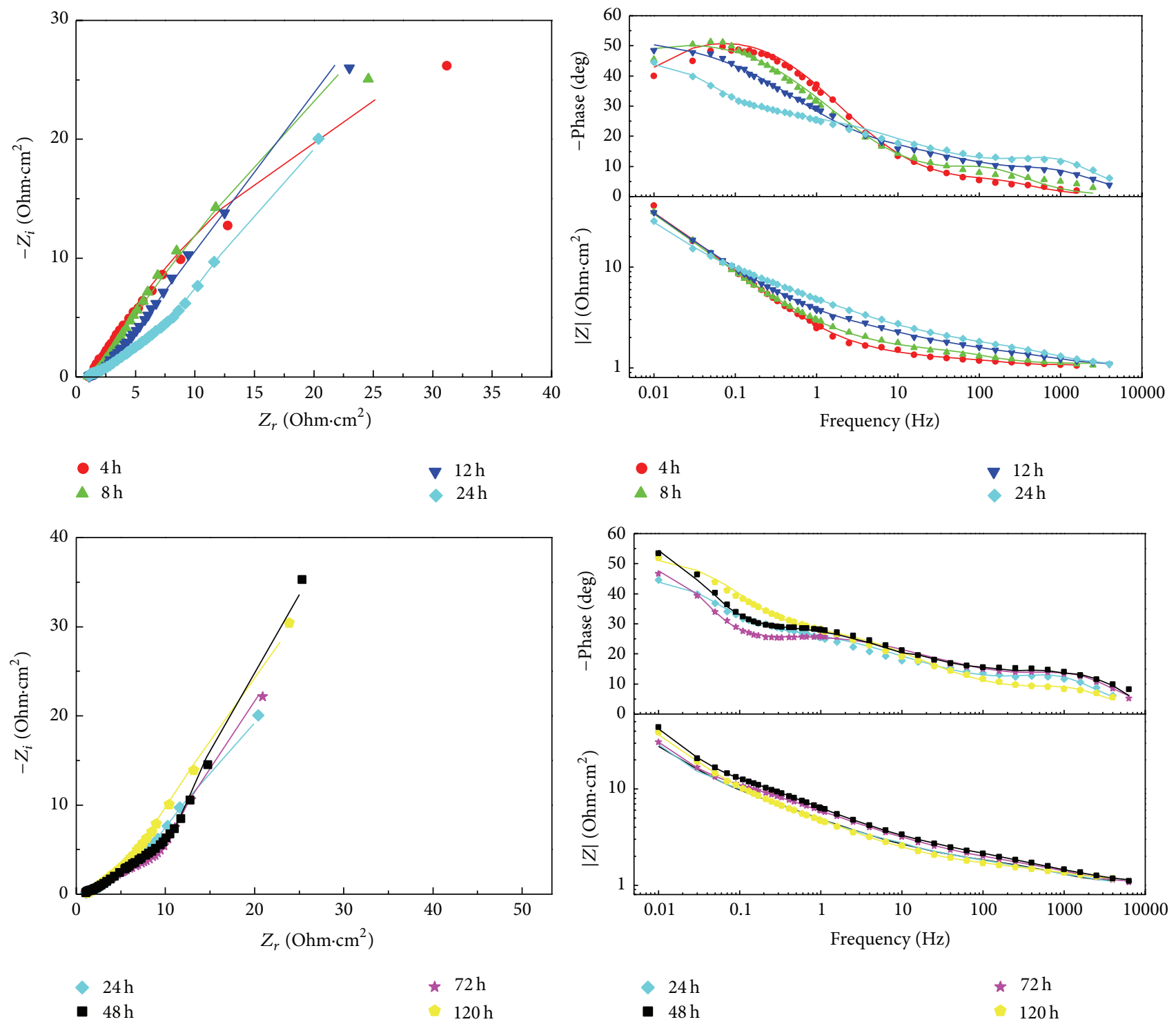

Figure 3: Nyquist and Bode plots of SS310 in molten carbonate at $650^{\circ} \mathrm{C}$ in air. Scattered points are measured data and lines are simulated data.

element (CPE) $\mathrm{Q}$ was used to describe the parameters $C_{\mathrm{dl}}$ and $C_{f}$ in the fitting procedure. The impedance spectra at 72 and $120 \mathrm{~h}$ of $\mathrm{P} 92$ were fit for the diffusion-controlled reaction, which could be simulated with the equivalent circuit in Figure 9(b), where $Z_{d}$ was the diffusion-induced resistance.

The Warburg resistance $Z_{d}$ can be expressed by (1). Consider

$$
Z_{d}=A_{d}(j \omega)^{-n_{d}}
$$

where $A_{d}$ is the modulus of diffusion-induced resistance and $n_{d}$ is the coefficient of diffusion impedance, ranging between 0 and 1 , related to the direction of the oxidants diffusion. When $n_{d}$ is equal to 0.5 , the diffusion direction of the oxidants is parallel to their concentration gradient in molten-salts and, accordingly, the slope of the line at low frequency in Nyquist plot is equal to 1 . When $n_{d}<0.5$, the diffusion direction of the oxidants deviates from their concentration gradient, a situation denoted by "tangential diffusion," and the slope of the line at low frequency in Nyquist plot is smaller than unity. When $n 0.5<n_{d}<1$, the diffusion process was impeded by obstacles, and the slope of the line at low frequency in Nyquist plot is smaller than unity.

According to the parameters in Table 2, the values of $R_{f}$ tend to increase and the values of $R_{c t}$ undulate with time prior to the appearance of Warburg impedance at the low frequency. This may be resulted from the trade-in between the outgrowth of oxide layer, which makes the oxide thicker, and the dissolution process which compromises the compactness of the scale. The appearance of $\mathrm{K}_{2} \mathrm{Fe}_{2} \mathrm{O}_{4}$ causes the abrupt appearance of the low-frequency loop and the small values of $A_{d}$ due to the porous nature of this oxide 


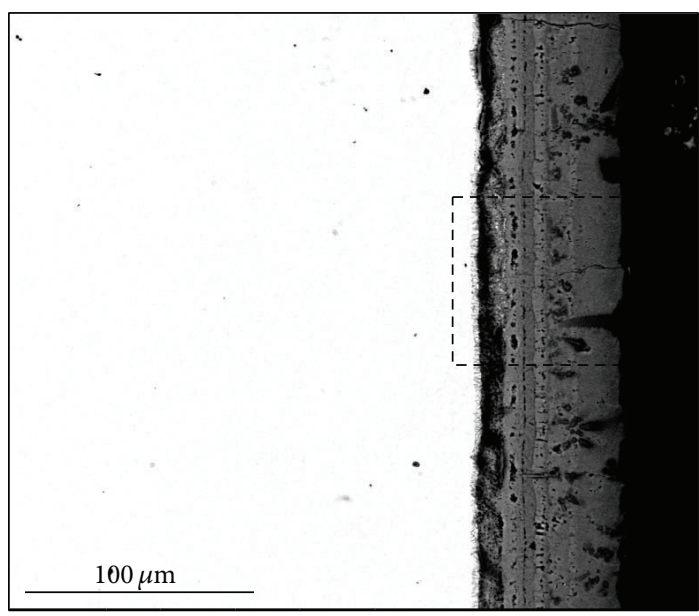

(a)

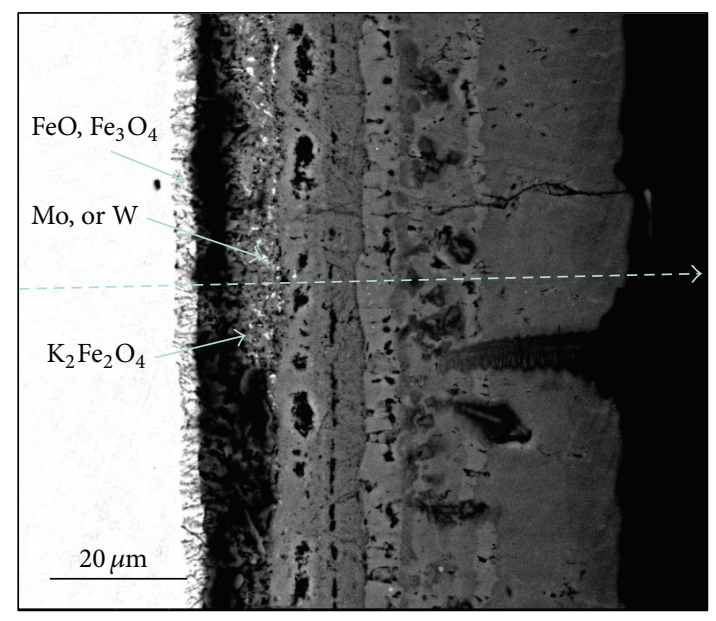

(b)

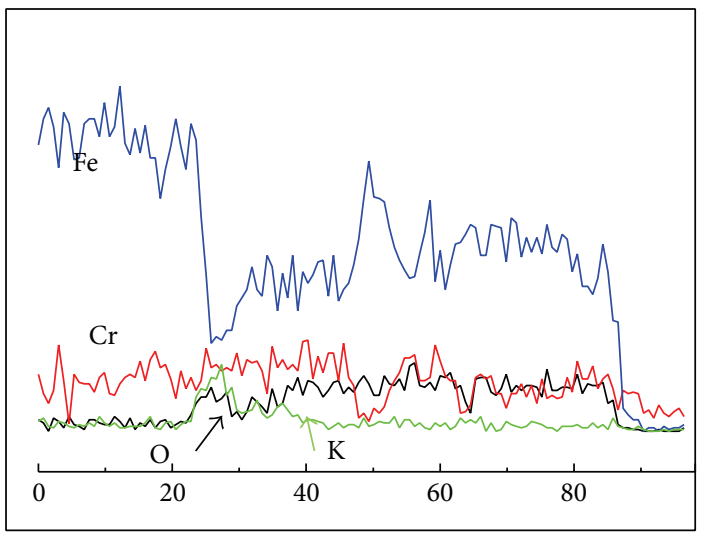

(c)

FIGURE 4: SEM morphology of P92 ((a) and (b)) after $120 \mathrm{~h}$ of corrosion in molten carbonate. (b) is the enlarged figures in the rectangles for (a). (c) is the EDX composition profile across the line in (b).

TABLE 2: Results of the CNLS fit to EIS data of P92.

\begin{tabular}{|c|c|c|c|c|c|c|c|c|c|c|}
\hline Time & $\begin{array}{c}R_{e} \\
\Omega \mathrm{cm}^{2}\end{array}$ & $\begin{array}{c}Y_{\mathrm{dl}} \\
\Omega^{-1} \mathrm{~S}^{-n_{\mathrm{dl}}} \mathrm{cm}^{-2}\end{array}$ & $n_{\mathrm{dl}}$ & $\begin{array}{c}R_{\mathrm{ct}} \\
\Omega \mathrm{cm}^{2}\end{array}$ & $\begin{array}{c}Y_{f} \\
\Omega^{-1} \mathrm{~S}^{-n_{\mathrm{dl}}} \mathrm{cm}^{-2}\end{array}$ & $n_{f}$ & $\begin{array}{c}R_{f} \\
\Omega \mathrm{cm}^{2}\end{array}$ & $\begin{array}{c}A_{d} \\
\Omega S^{n_{d}} \mathrm{~cm}^{2}\end{array}$ & $n_{d}$ & $\chi^{2}$ \\
\hline $4 \mathrm{~h}$ & 0.79 & $3.48 \times 10^{-2}$ & 0.49 & 3.54 & 0.20 & 0.44 & 116.50 & & & $1.0 \times 10^{-3}$ \\
\hline $8 \mathrm{~h}$ & 0.92 & $5.08 \times 10^{-3}$ & 0.70 & 1.76 & 0.16 & 0.47 & 46.99 & & & $4.0 \times 10^{-4}$ \\
\hline $12 \mathrm{~h}$ & 0.96 & $2.29 \times 10^{-3}$ & 0.77 & 1.89 & 0.13 & 0.45 & 103.90 & & & $7.4 \times 10^{-4}$ \\
\hline $24 \mathrm{~h}$ & 0.87 & $6.14 \times 10^{-3}$ & 0.63 & 2.54 & 0.20 & 0.58 & 65.06 & & & $5.2 \times 10^{-4}$ \\
\hline $48 \mathrm{~h}$ & 0.86 & $9.22 \times 10^{-3}$ & 0.61 & 2.62 & 0.25 & 0.57 & 31.13 & & & $6.1 \times 10^{-4}$ \\
\hline $72 \mathrm{~h}$ & 0.88 & $8.50 \times 10^{-3}$ & 0.61 & 2.19 & & & & 3.75 & 0.46 & $5.0 \times 10^{-4}$ \\
\hline $120 \mathrm{~h}$ & 0.86 & $1.58 \times 10^{-2}$ & 0.59 & 1.54 & & & & 2.79 & 0.39 & $1.1 \times 10^{-4}$ \\
\hline
\end{tabular}

and its damage on the integrity of scale. The $n_{d}$ value is less than 0.5 , indicating an infinite half-length diffusion affected by tangential diffusion process. Moreover, the decline of $R_{\mathrm{ct}}$ and $A_{d}$ suggest that the alloy suffered accelerated corrosion.

The impedance spectra of SS304 at all test times show only one time constant, close to the one at high-frequency part of P92, and are consisted of one line at low frequency and a loop, which can be simulated by equivalent circuit of Figure 9(b). This implies that the oxides on the surface may be permeable to the molten carbonate. In contrast to P92, the $R_{\mathrm{ct}}$ of SS304 increases persistently through the immersion test, from 1.77 to $3.17 \Omega \mathrm{cm}^{2}$, as shown in Table 3 . The $n_{d}$ values for simulated data of SS304 varied greatly from 0.73 to 0.47 , meaning the diffusion process shifted from a finite diffusion length due to the oxide growth to an infinite tangential diffusion. After the complete lithiation process of the $\mathrm{Fe}_{2} \mathrm{O}_{3}$, the porous $\mathrm{LiFeO}_{2}$ scale is not able to inhibit the diffusion of charged particles through the outer scale. The $R_{\mathrm{ct}}$ values undertook 


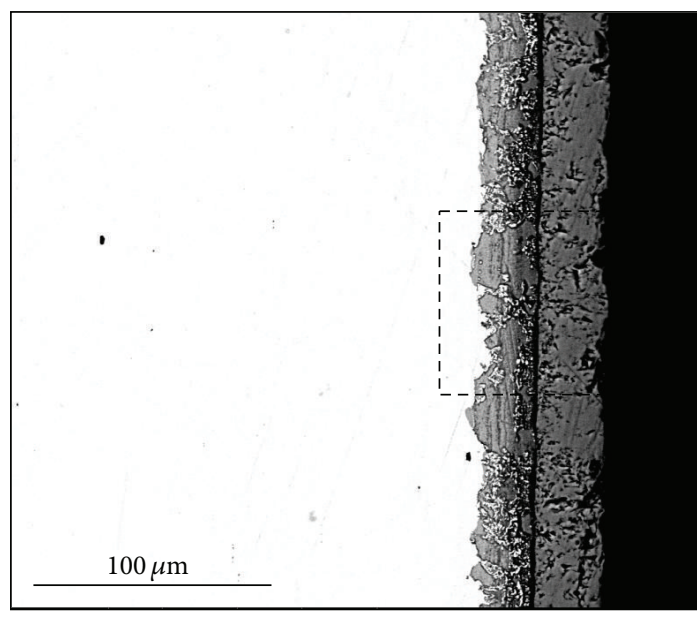

(a)

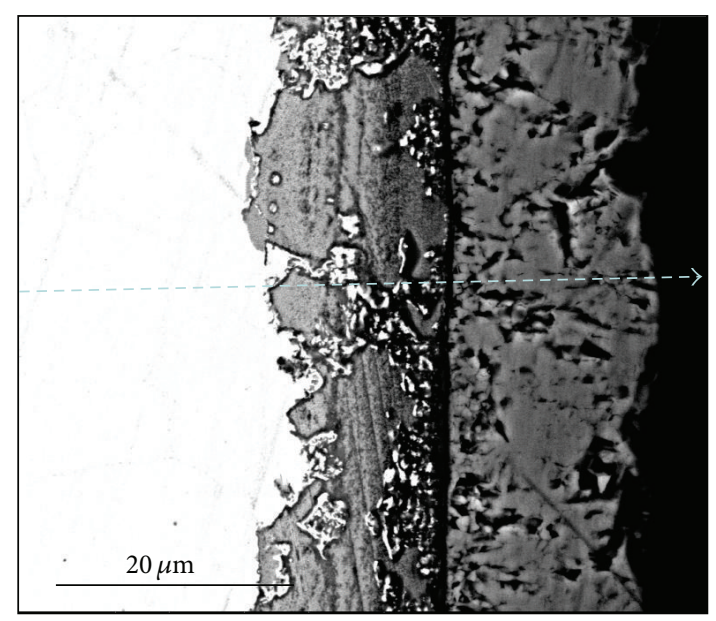

(b)

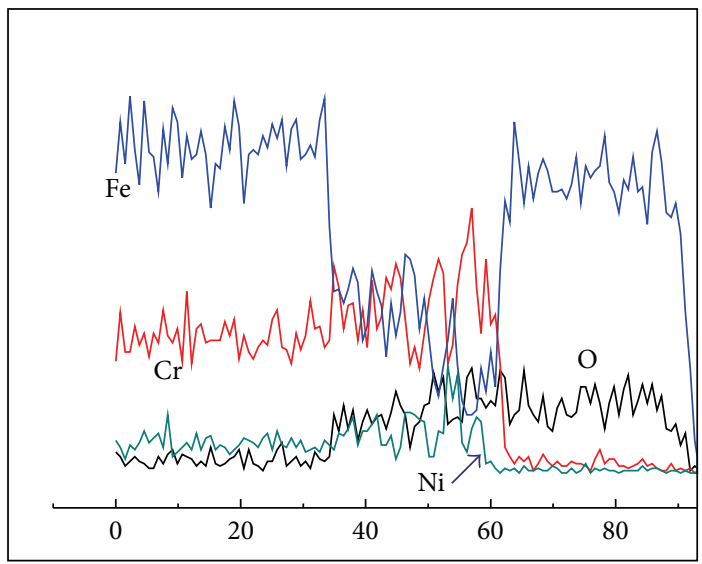

(c)

FIGURE 5: SEM morphology of SS304 ((a) and (b)) after $120 \mathrm{~h}$ of corrosion in molten carbonate. (b) is the enlarged figures in the rectangles for (a). (c) is the EDX composition profile across the line in (b).

TABLE 3: Results of the CNLS fit to EIS data of SS304.

\begin{tabular}{|c|c|c|c|c|c|c|c|}
\hline Time & $\begin{array}{c}R_{e} \\
\Omega \mathrm{cm}^{2}\end{array}$ & $\begin{array}{c}Y_{\mathrm{dl}} \\
\Omega^{-1} \mathrm{~S}^{-n_{\mathrm{dl}}} \mathrm{cm}^{-2}\end{array}$ & $n_{\mathrm{dl}}$ & $\begin{array}{c}R_{\mathrm{ct}} \\
\Omega \mathrm{cm}^{2}\end{array}$ & $\begin{array}{c}A_{d} \\
\Omega S^{n_{d}} \mathrm{~cm}^{2}\end{array}$ & $n_{d}$ & $\chi^{2}$ \\
\hline $4 \mathrm{~h}$ & 1.00 & $1.07 \times 10^{-1}$ & 0.58 & 1.77 & 3.81 & 0.73 & $3.9 \times 10^{-4}$ \\
\hline $8 \mathrm{~h}$ & 0.86 & $6.93 \times 10^{-2}$ & 0.47 & 1.67 & 2.85 & 0.70 & $4.3 \times 10^{-4}$ \\
\hline $12 \mathrm{~h}$ & 0.78 & $5.91 \times 10^{-2}$ & 0.43 & 2.13 & 2.52 & 0.68 & $7.4 \times 10^{-4}$ \\
\hline $24 \mathrm{~h}$ & 0.70 & $2.46 \times 10^{-2}$ & 0.47 & 2.34 & 2.56 & 0.54 & $5.3 \times 10^{-3}$ \\
\hline $48 \mathrm{~h}$ & 0.79 & $8.73 \times 10^{-3}$ & 0.61 & 2.54 & 3.71 & 0.46 & $5.4 \times 10^{-4}$ \\
\hline $72 \mathrm{~h}$ & 0.79 & $9.99 \times 10^{-3}$ & 0.59 & 2.84 & 3.89 & 0.47 & $1.0 \times 10^{-3}$ \\
\hline $120 \mathrm{~h}$ & 0.81 & $9.41 \times 10^{-3}$ & 0.59 & 3.17 & 3.65 & 0.47 & $4.0 \times 10^{-4}$ \\
\hline
\end{tabular}

a prevalent increase and $A_{d}$ remain fairly stable after the dip from 4 to $8 \mathrm{~h}$. The steady increase of $R_{\mathrm{ct}}$ could be a result of conductive spinel blocking layers which does not contribute to a distinguishable $R_{f}$ but blocks the transport of ionic particles between the metal and outer scale.

The impedance spectra before $12 \mathrm{~h}$ are showing two time constants and $\mathrm{LiFeO}_{2}$ scale was formed, so the equivalent circuit of Figure 9(a) is applicable to this circumstance. The impedance spectra after $24 \mathrm{~h}$ own a line in the low-frequency range showing diffusion-controlled reaction because the localized failure of oxide scales and the circuit of Figure 9(c) can be used to fit the impedance data in this case. Frangini and Loreti $[14,16]$ used similar equivalent circuit to simulate the impedance spectra of the corrosion of SS310 in molten carbonate. As can be seen from Table 4, the value of $R_{\mathrm{ct}}$ is much larger than that of $R_{f}$, the formation of oxide separated 
TABLE 4: Results of the CNLS fit to EIS data of SS310.

\begin{tabular}{lcccccccccc}
\hline Time & $\begin{array}{c}R_{e} \\
\Omega \mathrm{cm}^{2}\end{array}$ & $\begin{array}{c}Y_{f} \\
\Omega^{-1} \mathrm{~S}^{-n_{f}} \mathrm{~cm}^{-2}\end{array}$ & $n_{f}$ & $\begin{array}{c}R_{f} \\
\Omega \mathrm{cm}^{2}\end{array}$ & $\begin{array}{c}Y_{\mathrm{dl}} \\
\Omega^{-1} \mathrm{~S}^{-n_{\mathrm{dl}} \mathrm{cm}^{-2}}\end{array}$ & $n_{\mathrm{dl}}$ & $\begin{array}{c}R_{\mathrm{ct}} \\
\Omega \mathrm{cm}^{2}\end{array}$ & $\begin{array}{c}A_{d} \\
\Omega S^{n_{d}} \mathrm{~cm}^{2}\end{array}$ & $n_{d}$ & $\chi^{2}$ \\
\hline $4 \mathrm{~h}$ & 1.00 & $1.38 \times 10^{-1}$ & 0.63 & 2.85 & 0.02 & 0.87 & 87.07 & - & $6.9 \times 10^{-4}$ \\
$8 \mathrm{~h}$ & 1.09 & $9.92 \times 10^{-2}$ & 0.58 & 2.34 & 0.07 & 0.77 & 170.80 & - & $1.6 \times 10^{-3}$ \\
$12 \mathrm{~h}$ & 1.01 & $2.48 \times 10^{-2}$ & 0.56 & 1.19 & 0.11 & 0.57 & 25.88 & 49.50 & 0.87 & $8.2 \times 10^{-4}$ \\
$24 \mathrm{~h}$ & 0.89 & $4.25 \times 10^{-2}$ & 0.43 & 2.33 & 0.08 & 0.51 & 36.06 & 10.72 & 0.98 & $1.9 \times 10^{-3}$ \\
$48 \mathrm{~h}$ & 0.86 & $3.03 \times 10^{-2}$ & 0.43 & 2.99 & 0.04 & 0.59 & 24.14 & 8.23 & 0.98 & $7.0 \times 10^{-3}$ \\
$72 \mathrm{~h}$ & 1.06 & $2.01 \times 10^{-4}$ & 1.00 & 0.41 & 0.08 & 0.44 & 25.33 & 5.69 & 0.98 & $2.4 \times 10^{-4}$ \\
$120 \mathrm{~h}$ & 1.11 & $2.71 \times 10^{-4}$ & 1.00 & 0.32 & 0.08 & 0.53 & 11.42 & 11.90 & 0.77 & $1.6 \times 10^{-4}$ \\
\hline
\end{tabular}

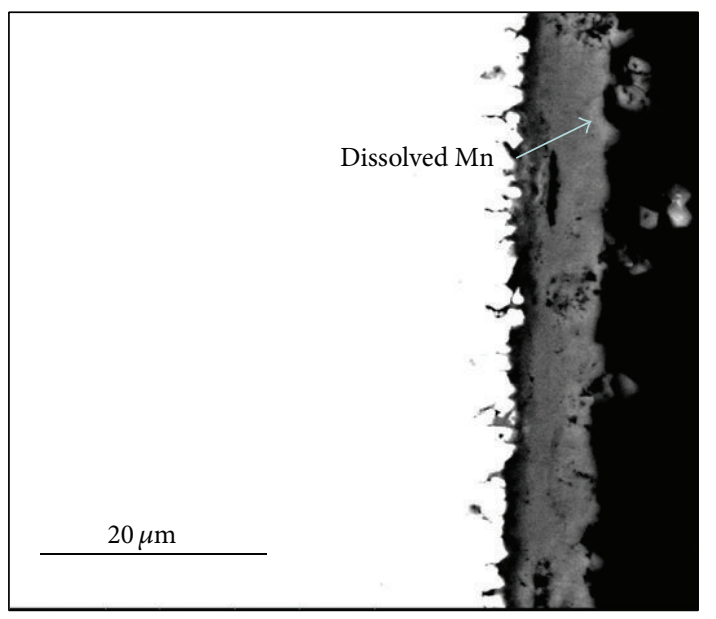

FIGURE 6: SEM morphology of SS310 after $120 \mathrm{~h}$ of corrosion in molten carbonate.

the base alloy from the molten salt, and the charge transfer process is inhibited by the transport of charged particles through the oxide scale. The formation of chromium scale can be used to interpret the large $R_{f}$ in the first 8 hours and the lithiation happened can cause the abrupt decrease of resistance and appearance of Warburg impedance from 12 hours on. After the diffusion element appears, its value varies greatly with immersion time, and so was the value of $R_{\mathrm{ct}}$, indicating the alteration of growth and dissolution of scales during the corrosion process. However, the $n_{d}$ is always larger than 0.5 , suggesting that the diffusion process is influenced by the outgrowth of scale and lithiation process that causes the infinite diffusion [16]. Unlike the $n_{d}$ values for SS304 which decrease from 0.73 to 0.47 , the values for SS310 are above 0.77 and slightly decrease over the immersion times, indicating that the lithiation of the scale of SS310 lasts longer times.

3.4. Validation of the Modeling with a Replicate. Because the growth of a corrosion layer is a nucleation and growth process, the small differences in the surface composition can lead to different corrosion products and varied kinetics of surface passivation and the microstructure of the scale.
Keijzer et al. [28] reported the three distinct open-circuit potential variations within the first 24-hour immersion, which indicates that the corrosion of Cr-containing steel can vary with small perturbation at the initial stage. The electrochemical impedance measurements with the 120 hours for the three alloys are repeated, as is called replicate, and the modeling parameters are represented in Figure 10. One can see that the $R_{\mathrm{ct}}$ values for the three alloys are different by the first 40 hours of immersion, but they converge to each other at the end of the immersion test. Even though there is a 10 hours of lag between the appearance of diffusion-related element for the two replicates of P92 and SS304, the modeling still holds during the 120-hour measurement. The $A_{d}$ value for the three alloys varies with time, but the difference between the two measurements for the same alloys diminishes at the end of the immersion tests. The abrupt decrease of $A_{d}$ of P92 at $85 \mathrm{~h}$ could be an abrupt appellation of the protective scale. The $n_{d}$ values for $\mathrm{P} 92$ are smaller than 0.5 but those for SS304 decrease from 0.7 at the beginning to less than 0.5 at 120 hours. After the complete lithiation of the external $\mathrm{Fe}_{2} \mathrm{O}_{3}$ film, the $n_{d}$ values are going to be less than 0.5 . At the very beginning of appearance of $Z_{d}$, the $n_{d}$ values for both SS310 samples are close to 0.9 , but the replicate shows an $n_{d}$ value smaller than 0.5 after 60 hours, in contrast to the $n_{d}$ values listed in Table 4 . The low $n_{d}$ value suggests that the diffusion in the microfissures of lithiation process is negligible; this could be a result of denser chromia film on the metal/scale surface, as indicated by the larger $R_{\mathrm{ct}}$ of this sample during 10 to $40 \mathrm{~h}$ and larger $A_{d}$ value between 40 and $100 \mathrm{~h}$. It is also possible that the $n_{d}$ value of the SS310 will decrease to a value below 0.5 in longer immersion than 120 hours, as the replicate does at 48 hours.

\section{Discussion}

The corrosion of stainless steel is very complex because of the large number of components comprising the steel and because it can form multiple corrosion layers with mixed compositions. However, the oxidation of the metallic elements of the alloys can be reduced to the cathodic and anodic reactions: on the cathode side, the solubility of oxygen molecular in molten carbonate is rather small, and thus, before being reduced, it will be reduced to form $\mathrm{O}_{2}{ }^{-}$or $\mathrm{O}_{2}{ }^{2-}$ through reactions (2) and (3), respectively, which then was 


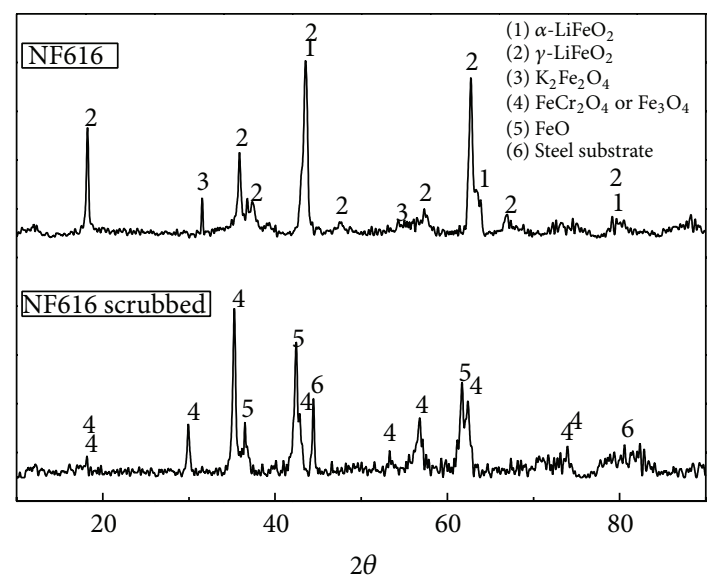

(a)

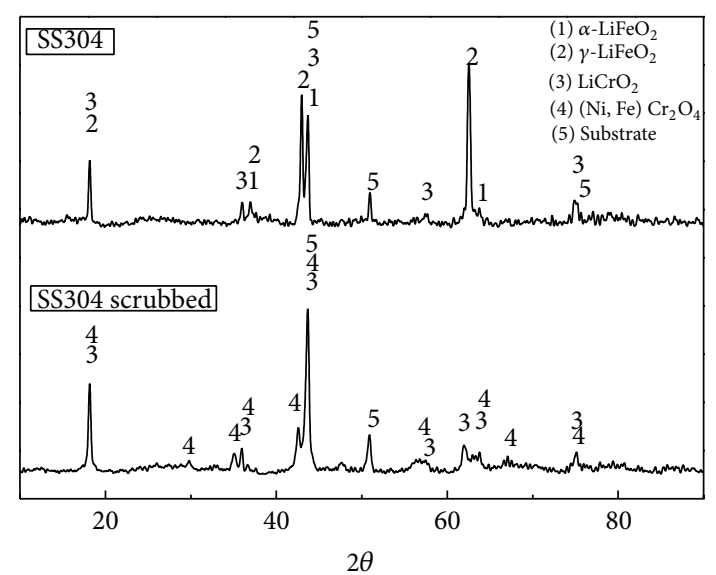

(b)

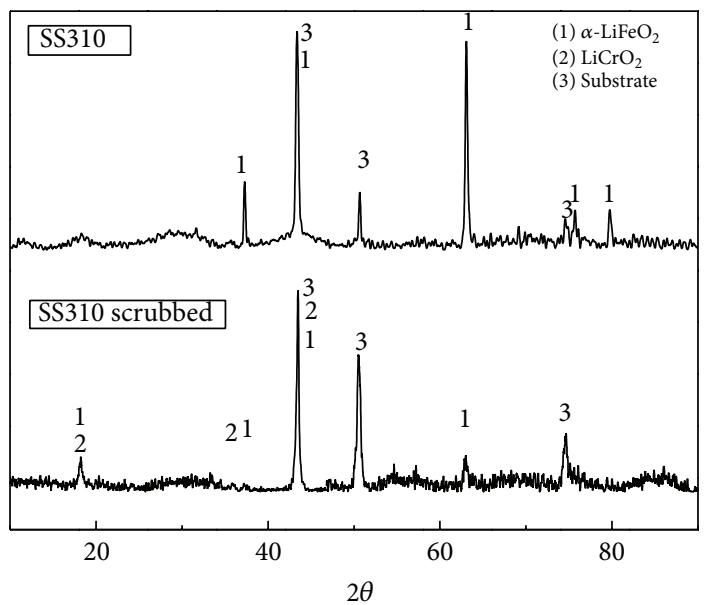

(c)

FIGURE 7: XRD patterns for corrosion products on P92 (a), SS304 (b), and SS310 (c) after $120 \mathrm{~h}$ of immersion in molten carbonate.

reduced to oxygen ion by the electrons provided by the anode reaction as in reaction $(4)$ or $(5)[21,29]$

$$
\begin{gathered}
3 \mathrm{O}_{2}+2 \mathrm{CO}_{3}{ }^{2-} \longrightarrow 4 \mathrm{O}_{2}{ }^{-}+2 \mathrm{CO}_{2} \uparrow \\
\mathrm{O}_{2}+2 \mathrm{CO}_{3}{ }^{2-} \longrightarrow 2 \mathrm{O}_{2}{ }^{2-}+2 \mathrm{CO}_{2} \uparrow \\
\mathrm{O}_{2}{ }^{2-}+2 \mathrm{e}^{-} \longrightarrow 2 \mathrm{O}^{2-} \\
\mathrm{O}_{2}^{-}+3 \mathrm{e}^{-} \longrightarrow 2 \mathrm{O}^{2-}
\end{gathered}
$$

Which reaction prevails depends on the acidity of the melt, and, in our case, reactions (2) and (4) are the dominant reaction routes of oxygen in molten carbonate [30, 31].

On the anode, the metallic element $\mathrm{M}$ will be oxidized through the reaction

$$
\mathrm{M}+n \mathrm{e}^{-} \longrightarrow \mathrm{M}^{n+} \text { ( } n \text { is the number of electrons) }
$$

The metallic ion combines with oxygen ion to form oxide, which can react with $\mathrm{Li}_{2} \mathrm{CO}_{3}$ or $\mathrm{K}_{2} \mathrm{CO}_{3}$ to produce ternary oxide.

When the Fe-Cr alloys are immersed in the molten carbonate, chromium oxidizes faster than iron, and chromium oxide dissolves much faster than iron oxide into the carbonate under cathode gas [28]. Hence, when the chromium oxide dissolves, a layer of iron oxide remains on the metal surface, and then it is lithiated to form lithium ferrite, whose solubility is determined to be 78 weight ppm in molten $\left(\mathrm{Li}_{0.62}\right.$, $\left.\mathrm{K}_{0.38}\right) \mathrm{CO}_{3}$ at $650^{\circ} \mathrm{C}$ [32]. Unfortunately, it is too porous to prevent the corrosion of underlying metallic element. The corrosion process of the three alloys diverged from one another thanks to the difference in chromium content and their manner of reaction with carbonate. The scale on the surface of the alloy could possibly be a mixture $\mathrm{LiFeO}_{2}$ and $\mathrm{LiCrO}_{2}$ depending on the $\mathrm{Cr}$ content.

The chromium content of $\mathrm{P} 92$ was so low that no inner chromium oxide layer, though the outer $\mathrm{LiFeO}_{2}$ was supposed to prevent the oxide from catastrophic reaction with the molten carbonate. As the fast diffusion of inward oxygen ion and outward diffusion were not curbed that no Feor Cr-dominant scale can be distinguished throughout the scale, leaving slightly $\mathrm{Fe}$ - or $\mathrm{Cr}$-enriched layers due to the difference of diffusion speed of $\mathrm{Fe}$ and $\mathrm{Cr}$ ion, the existence of continuous porous oxide layer also concurred with the EIS data and proposed model. Given enough time, $\mathrm{FeO}, \mathrm{FeCr}_{2} \mathrm{O}_{4}$, 

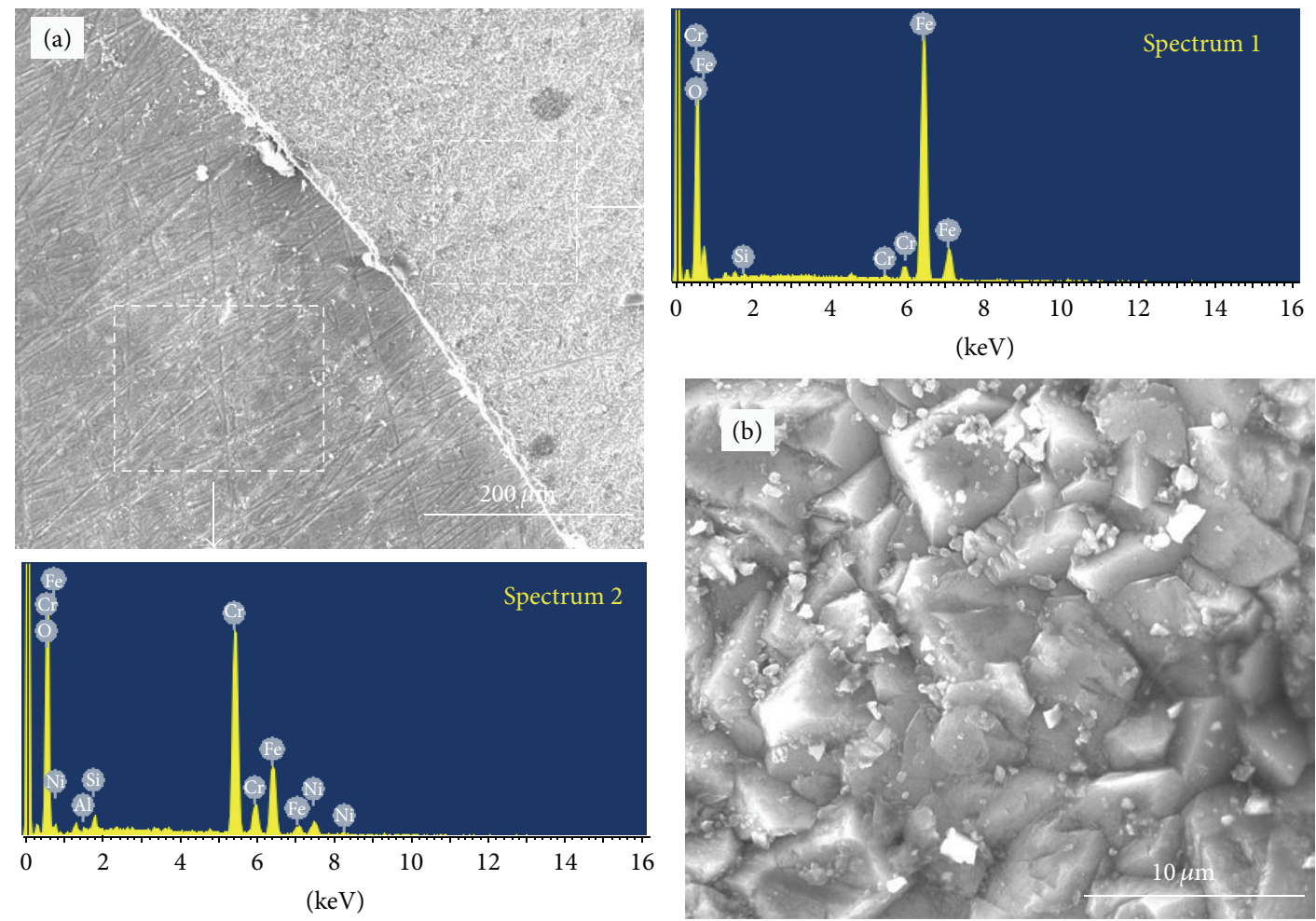

FIGURE 8: Surface morphology and EDX of the corrosion products on SS304 after $120 \mathrm{~h}$ of immersion in molten carbonate at $650^{\circ} \mathrm{C}$. (a) is the overview of the region where the outermost layer was partly spalled off and (b) is the enlarged view of the outermost layer.

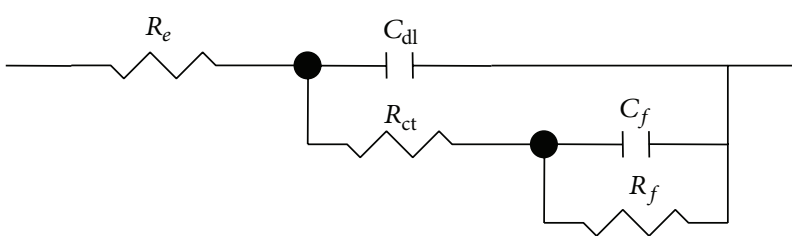

(a)

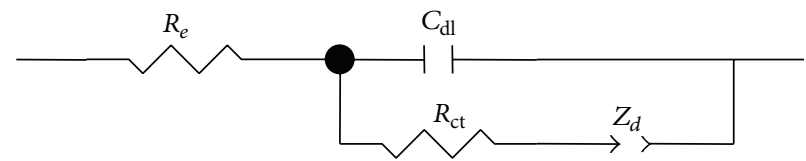

(b)

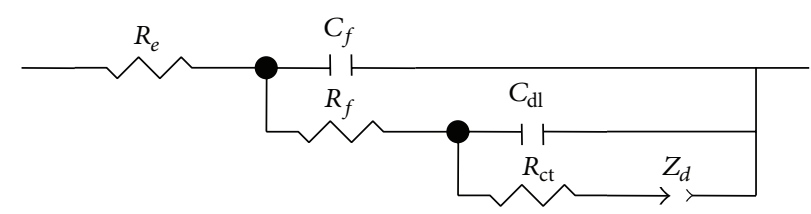

(c)

FIgURE 9: Equivalent circuits for the corrosion of the three stainless steels in molten carbonate at $650^{\circ} \mathrm{C}$.

or $\mathrm{Fe}_{3} \mathrm{O}_{4}$ were able to precipitate where the oxygen pressure was low enough beneath the thick $\mathrm{LiFeO}_{2}$ layer, but they are confined to a $2 \mu \mathrm{m}$ region on the bulk-metal surface. According to the cross section image, the inner layer was even more porous than the outer layer, so the scale is permeable to molten carbonate and the corrosion process was now subject to the diffusion of ions in molten carbonate. Judging from the simulated parameters of $R_{\mathrm{ct}}$ and $A_{d}$ at this stage, the corrosion process was expedited along with the thickening of inner layer. The $\mathrm{K}_{2} \mathrm{Fe}_{2} \mathrm{O}_{4}$ is highly porous and, in the formation process, the $\mathrm{CO}_{2}$ is produced through reaction (6) to enhance the delamination of scale from the substrate

$$
\mathrm{Fe}_{2} \mathrm{O}_{3}+\mathrm{K}_{2} \mathrm{CO}_{3}=\mathrm{K}_{2} \mathrm{Fe}_{2} \mathrm{O}_{4}+\mathrm{CO}_{2} \uparrow
$$

Because SS304 contained 19.3 wt.\% Cr, a chromium-rich oxide layer (67\% $\mathrm{Cr}-26 \% \mathrm{Fe}-7 \% \mathrm{Ni}$ in atomic percent) was able to persist beneath the $\mathrm{LiFeO}_{2}$ layer as the thin cap on top of the intermediate layer. This impure chromium oxide layer was able to impede to some extent the diffusion of the inward 


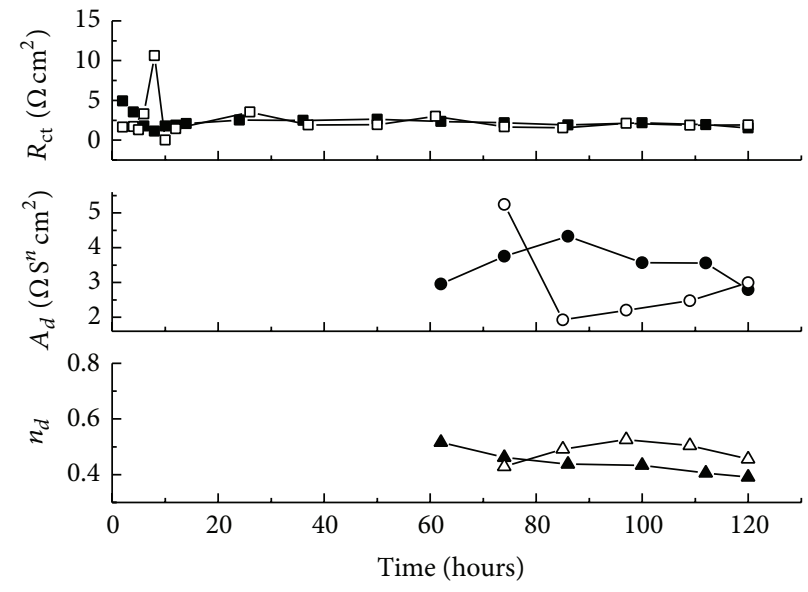

(a)
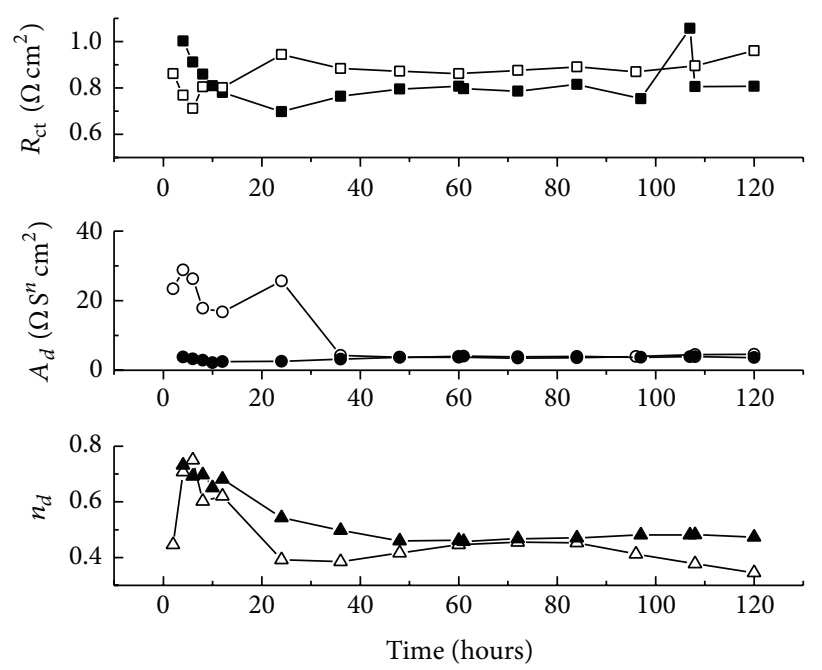

(b)
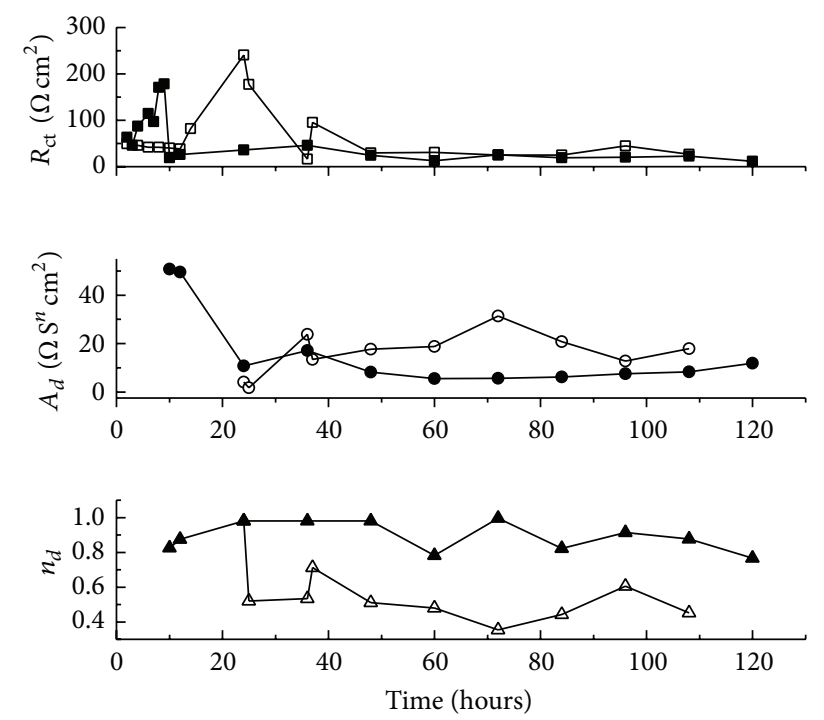

(c)

Figure 10: Comparison of the simulated parameters of the P92 (a), SS304 (b), and SS310 (c) between two repetitions in terms of $R_{\mathrm{ct}}$ (square), $A_{d}$ (circle), and $n_{d}$ (circle). The filled data corresponding to those listed in tables and the open mark are the replicate.

oxygen ion and outward metallic ion, as indicated by $n_{d}>0.5$. With extended time, insufficient chromium diffused from the substrate side to support the growth of oxide and thus the chromium content decreased gradually inward after $120 \mathrm{~h}$ of corrosion. The composite of $(\mathrm{Ni}, \mathrm{Fe}) \mathrm{Cr}_{2} \mathrm{O}_{4}, \mathrm{LiCrO}_{2}, \mathrm{LiFeO}_{2}$, and Ni-rich metallic particle that replaced the chromiumrich layer undermined the blocking effect of the chromiumrich oxide layer and thus Warburg impedance appeared at $48 \mathrm{~h}$. Previous investigations of the corrosion of Fe-based alloys with similar content of $\mathrm{Ni}$ and $\mathrm{Cr}$ in molten carbonate [8] revealed that the formation of $\mathrm{LiFeO}_{2}$ was controlled by outward diffusion of $\mathrm{Fe}$ ion and the formation of $(\mathrm{Ni}$, $\mathrm{Fe})_{2} \mathrm{CrO}_{4}$ by inward diffusion or transport of oxygen ion, which explained the wavy interface between the matrix and spinel oxide. In the spots where the diffusion path of oxygen ion were blocked by heterogeneous inclusions like nickel particles or $\mathrm{LiCrO}_{2}$ aggregations, the matrix underwent slower oxidation as shown in Figure 5(b). The blocking effect of the spinels causes the unbalanced diffusion path and the resultant indented scale structure.

There was sufficient chromium in SS310 to form abundant chromium oxides which precipitated immediately after the formation of outer $\mathrm{LiFeO}_{2}$ layer, and the alloy suffered a resultant localized fast corrosion. From $12 \mathrm{~h}$ onward, a continuous chromium oxide, that is, $\mathrm{LiCrO}_{2}$, layer was formed that the diffusion of the ions was blocked by the continuous inner layer, so an infinite diffusion reaction can be seen from the simulated parameters. Takeuchi et al. [17] reported that when the chromium content is up to $25 \mathrm{wt}$.\% in $\mathrm{Fe}-\mathrm{Cr}$ alloy, the composite of $\mathrm{LiCrO}_{2}$ and $\mathrm{LiFeO}_{2}$ tended to disappear. Ahn et al. [33] reported that the decrease in the corrosion rate of SS310 is much greater than that on SS316 at the initial stage 
of the corrosion process, thanks to the higher $\mathrm{Cr}$ content in SS310. At extended immersion times, the formation of $\mathrm{K}_{2} \mathrm{CrO}_{4}$ is possible and contributes to the $\mathrm{Cr}$ loss from the inner scale, though we did not observe this in our study. From our study, we found that the significantly thinner scale on SS310 after $120 \mathrm{~h}$ compared with that on SS304 is very likely due to purer $\mathrm{LiCrO}_{2}$ layer, which could be a result of dense chromia layer at the initial stage.

\section{Conclusion}

EIS has been applied to monitor the corrosion of three stainless steels in molten carbonate at $650^{\circ} \mathrm{C}$ for extended times. Proper equivalent circuits were proposed to explain the corrosion mechanism by analyzing the impedance data in combination with laminated XRD pattern and microscopy images. Due to the high chromium content, SS310 was the only alloy that formed compact pure $\mathrm{LiCrO}_{2}$ which prevents the diffusion of $\mathrm{Fe}$ ion and oxygen species. Although a chromium layer appeared to prevent the transport of materials at the beginning, the blocking layer, which contained large amount of $\mathrm{LiFeO}_{2}$, disintegrated afterwards and a spinel layer was formed in the matrix side for SS304. With insufficient chromium, P92 was not able to from any chromium-rich layer throughout the whole test. A double-layer scale formed, on the surface, an outer layer containing $\mathrm{LiFeO}_{2}$ and $\mathrm{K}_{2} \mathrm{FeO}_{2}$ and a porous inner layer containing $\mathrm{FeO}$ and $\mathrm{Fe}_{3} \mathrm{O}_{4} / \mathrm{FeCr}_{2} \mathrm{O}_{4}$.

\section{Conflict of Interests}

The authors declare that there is no conflict of interests regarding the publication of this paper.

\section{Acknowledgment}

This work was supported by the National Natural Science Foundation of China under Contracts nos. 51371183 and 50971129 .

\section{References}

[1] M. Palm, "Fe-Al materials for structural applications at high temperatures: current research at MPIE," International Journal of Materials Research, vol. 100, no. 3, pp. 277-287, 2009.

[2] C. S. Ni, L. Y. Lu, C. L. Zeng, and Y. Niu, "Evaluation of corrosion resistance of aluminium coating with and without annealing against molten carbonate using electrochemical impedance spectroscopy," Journal of Power Sources, vol. 261, pp. 162-169, 2014.

[3] S. Freni, S. Cavallaro, M. Aquino, D. Ravida, and N. Giordano, "Lifetime-limiting factors for a molten carbonate fuel cell," International Journal of Hydrogen Energy, vol. 19, no. 4, pp. 337341, 1994.

[4] P. Biedenkopf, M. M. Bischoff, and T. Wochner, "Corrosion phenomena of alloys and electrode materials in Molten carbonate fuel cells," Materials and Corrosion, vol. 51, pp. 287-302, 2000.

[5] A. C. Schoeler, T. D. Kaun, I. Bloom, M. Lanagan, and M. Krumpelt, "Corrosion behavior and interfacial resistivity of bipolar plate materials under molten carbonate fuel cell cathode conditions," Journal of the Electrochemical Society, vol. 147, no. 3, pp. 916-921, 2000.

[6] C. Yuh, R. Johnsen, M. Farooque, and H. Maru, "Status of carbonate fuel cell materials," Journal of Power Sources, vol. 56, no. 1, pp. 1-10, 1995.

[7] M. Spiegel, P. Biedenkopf, and H. J. Grabke, "Corrosion of iron base alloys and high alloy steels in the $\mathrm{Li}_{2} \mathrm{CO}_{3}-\mathrm{K}_{2} \mathrm{CO}_{3}$ eutectic mixture," Corrosion Science, vol. 39, no. 7, pp. 1193-1210, 1997.

[8] P. Biedenkopf, M. Spiegel, and H. J. Grabke, "High temperature corrosion of low and high alloy steels under molten carbonate fuel cell conditions," Materials and Corrosion, vol. 48, no. 8, pp. 477-488, 1997.

[9] Z. Chaoliu, G. Pingyi, and W. Weitao, "Electrochemical impedance of two-phase Ni-Ti alloys during corrosion in eutectic $(0.62 \mathrm{Li}, 0.38 \mathrm{~K})_{2} \mathrm{CO}_{3}$ at 650 ○C," Electrochimica Acta, vol. 49 , no. 14, pp. 2271-2277, 2004.

[10] C. L. Zeng, W. Wang, and W. T. Wu, "Electrochemical-impedance study of the corrosion of $\mathrm{Ni}$ and $\mathrm{FeAl}$ intermetallic alloy in molten $(0.62 \mathrm{Li}, 0.38 \mathrm{~K})_{2} \mathrm{CO}_{3}$ at $650 \circ \mathrm{C}$," Oxidation of Metals, vol. 53, no. 3, pp. 289-302, 2000.

[11] F. J. Pérez, M. P. Hierro, D. Duday, C. Gómez, M. Romero, and L. Daza, "Hot-corrosion studies of separator plates of AISI310 stainless steels in molten-carbonate fuel cells," Oxidation of Metals, vol. 53, no. 3, pp. 375-398, 2000.

[12] B. Young Yang and K. Young Kim, "The oxidation behavior of $\mathrm{Ni}-50 \%$ Co alloy electrode in molten $\mathrm{Li}+\mathrm{K}$ carbonate eutectic," Electrochimica Acta, vol. 44, no. 13, pp. 2227-2234, 1999.

[13] S. A. Salih, A. N. El-Masri, and A. M. Baraka, "Corrosion behaviour of some stainless steel alloys in molten alkali carbonates (I)," Journal of Materials Science, vol. 36, no. 10, pp. 25472555, 2001.

[14] S. Frangini, “Testing procedure to obtain reliable potentiodynamic polarization curves on type $310 \mathrm{~S}$ stainless steel in alkali carbonate melts," Materials and Corrosion, vol. 57, no. 4, pp. 330-337, 2006.

[15] B. Zhu, G. Lindbergh, and D. Simonsson, "Comparison of electrochemical and surface characterisation methods for investigation of corrosion of bipolar plate materials in molten carbonate fuel cell Part I. Electrochemical study," Corrosion Science, vol. 41, no. 8, pp. 1497-1513, 1999.

[16] S. Frangini and S. Loreti, "The role of temperature on the corrosion and passivation of type $310 \mathrm{~S}$ stainless steel in eutectic $(\mathrm{Li}+\mathrm{K})$ carbonate melt," Journal of Power Sources, vol. 160, no. 2, pp. 800-804, 2006.

[17] K. Takeuchi, A. Nishijima, K. Ui, N. Koura, and C.-K. Loong, "Corrosion behavior of $\mathrm{Fe}-\mathrm{Cr}$ alloys in $\mathrm{Li}_{2} \mathrm{CO}_{3}-\mathrm{K}_{2} \mathrm{CO}_{3}$ molten carbonate," Journal of the Electrochemical Society, vol. 152, no. 9, pp. B364-B368, 2005.

[18] C. L. Zeng, P. Y. Guo, and W. T. Wu, "Electrochemical impedance spectra for the corrosion of two-phase $\mathrm{Cu}-15 \mathrm{Al}$ alloy in eutectic $(\mathrm{Li}, \mathrm{K})_{2} \mathrm{CO}_{3}$ at $650 \circ \mathrm{C}$ in air," Electrochimica Acta, vol. 49, no. 9-10, pp. 1445-1450, 2004.

[19] S. Frangini, "Corrosion of metallic stack components in molten carbonates: critical issues and recent findings," Journal of Power Sources, vol. 182, no. 2, pp. 462-468, 2008.

[20] J. Youn, B. Ryu, M. Shin et al., "Effect of $\mathrm{CO}_{2}$ partial pressure on the cathode lithiation in molten carbonate fuel cells," International Journal of Hydrogen Energy, vol. 37, no. 24, pp. 19289-19294, 2012.

[21] T. Nishina, I. Uchida, and J. R. Selman, "Gas electrode reactions in molten carbonate media. Part V. Electrochemical analysis 
of the oxygen reduction mechanism at a fully immersed gold electrode," Journal of the Electrochemical Society, vol. 141, no. 5, pp. 1191-1198, 1994.

[22] K.-I. Ota, K. Toda, S. Mitsushima, and N. Kamiya, "Accelerated corrosion of stainless steels with the presence of molten carbonates below $923 \mathrm{~K}$," Bulletin of the Chemical Society of Japan, vol. 75, no. 4, pp. 877-881, 2002.

[23] C. S. Ni, L. Y. Lu, C. L. Zeng, and Y. Niu, "Electrochemical impedance studies of the initial-stage corrosion of $310 \mathrm{~S}$ stainless steel beneath thin film of molten $(0.62 \mathrm{Li}, 0.38 \mathrm{~K})_{2} \mathrm{CO}_{3}$ at $650^{\circ} \mathrm{C}$," Corrosion Science, vol. 53, no. 3, pp. 1018-1024, 2011.

[24] S. Mitsushima, Y. Nishimura, N. Kamiya, and K.-I. Ota, "Corrosion model for iron in the presence of molten carbonate," Journal of the Electrochemical Society, vol. 151, no. 6, pp. A825A830, 2004.

[25] I. Parezanović, E. Strauch, and M. Spiegel, "Development of spinel forming alloys with improved electronic conductivity for MCFC applications," Journal of Power Sources, vol. 135, no. 1-2, pp. 52-61, 2004.

[26] H. Yakakawa, N. Sakai, T. Kawada, M. Dokiya, and K.-I. Ota, "Chemical potential diagrams for Fe-Cr-Li-K-C-O system: thermodynamic analysis on reaction profiles between alloys and alkali carbonate," Journal of the Electrochemical Society, vol. 140, no. 12, pp. 3565-3577, 1993.

[27] M. Spiegel, "Salt melt induced corrosion of metallic materials in waste incineration plants," Materials and Corrosion, vol. 50, no. 7, pp. 373-393, 1999.

[28] M. Keijzer, G. Lindbergh, K. Hemmes, P. J. J. M. van der Put, J. Schoonman, and J. H. W. de Wit, "Corrosion of 304 stainless steel in molten-carbonate fuel cells," Journal of the Electrochemical Society, vol. 146, no. 7, pp. 2508-2516, 1999.

[29] S. Frangini and S. Scaccia, "The role of foreign cations in enhancing the oxygen solubility properties of alkali molten carbonate systems: Brief survey of existing data and new research results," International Journal of Hydrogen Energy, vol. 39, pp. 12266-12272, 2014.

[30] J. G. Gonzalez-Rodriguez, M. Cuellar-Hernández, M. Gonzalez-Castañeda, V. M. Salinas-Bravo, J. Porcayo-Calderon, and G. Rosas, "Effect of heat treatment and chemical composition on the corrosion behavior of FeAl intermetallics in molten $(\mathrm{Li}+$ K) carbonate," Journal of Power Sources, vol. 172, no. 2, pp. 799804, 2007.

[31] F. J. Pérez, D. Duday, M. P. Hierro et al., "Hot corrosion study of coated separator plates of molten carbonate fuel cells by slurry aluminides," Surface and Coatings Technology, vol. 161, no. 2-3, pp. 293-301, 2002.

[32] H. S. Hsu, J. H. DeVan, and M. Howell, "Solubilities of $\mathrm{LiFeO}_{2}$ and $(\mathrm{Li}, \mathrm{K})_{2} \mathrm{CrO}_{4}$ in Molten Alkali carbonates at $650^{\circ} \mathrm{C}$," Journal of the Electrochemical Society, vol. 34, no. 9, pp. 2146-2150, 1987.

[33] S. Ahn, K. Oh, M. Kim et al., "Electrochemical analysis on the growth of oxide formed on stainless steels in molten carbonate at 650 ○C, International Journal of Hydrogen Energy, vol. 39, no. 23, pp. 12291-12299, 2014. 

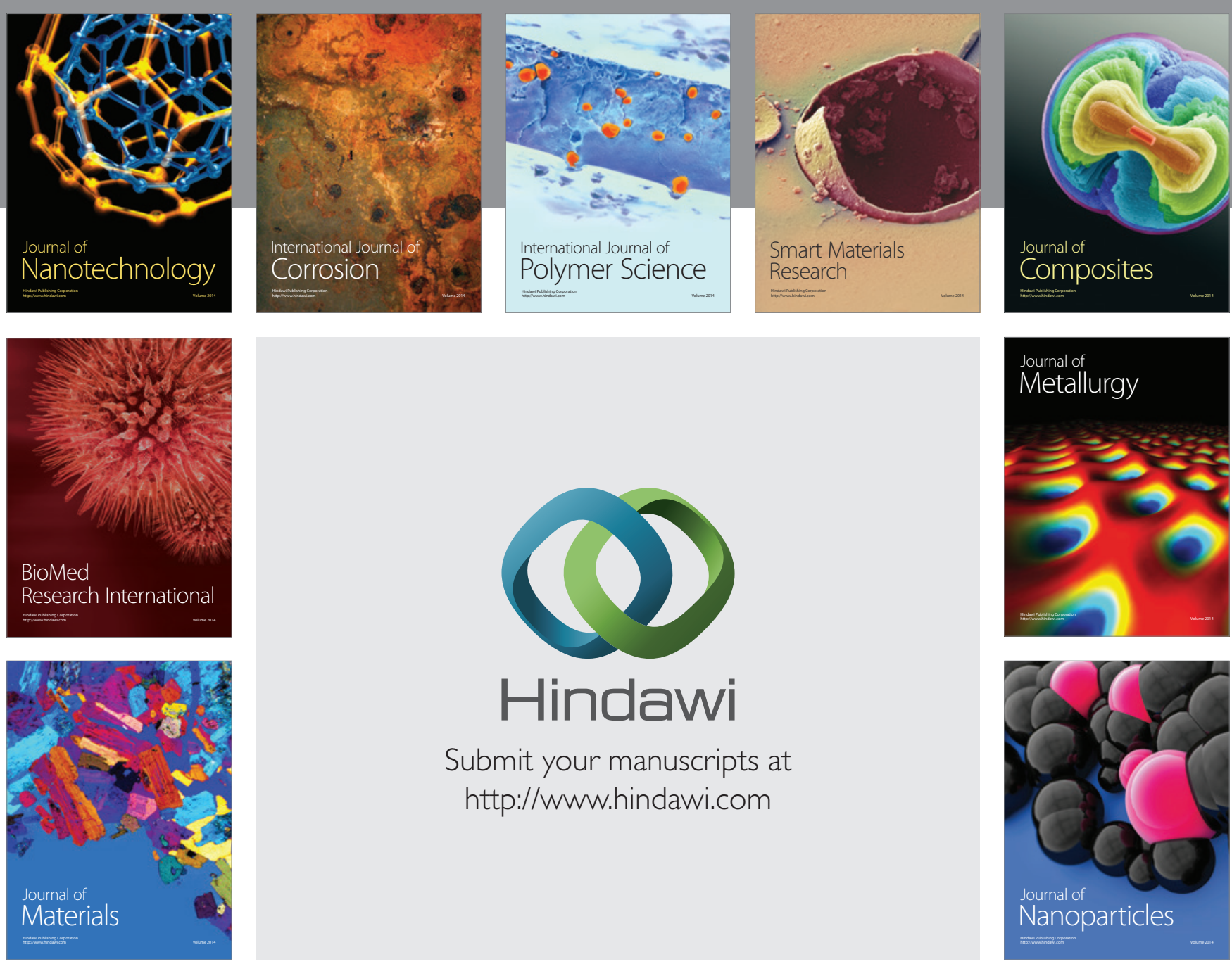

Submit your manuscripts at http://www.hindawi.com
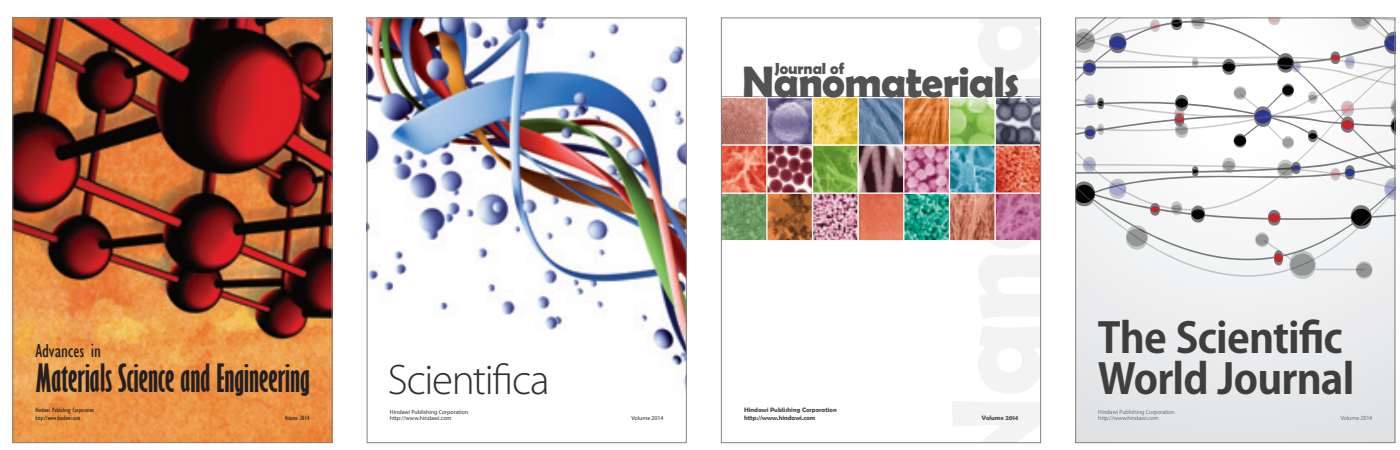

\section{The Scientific World Journal}
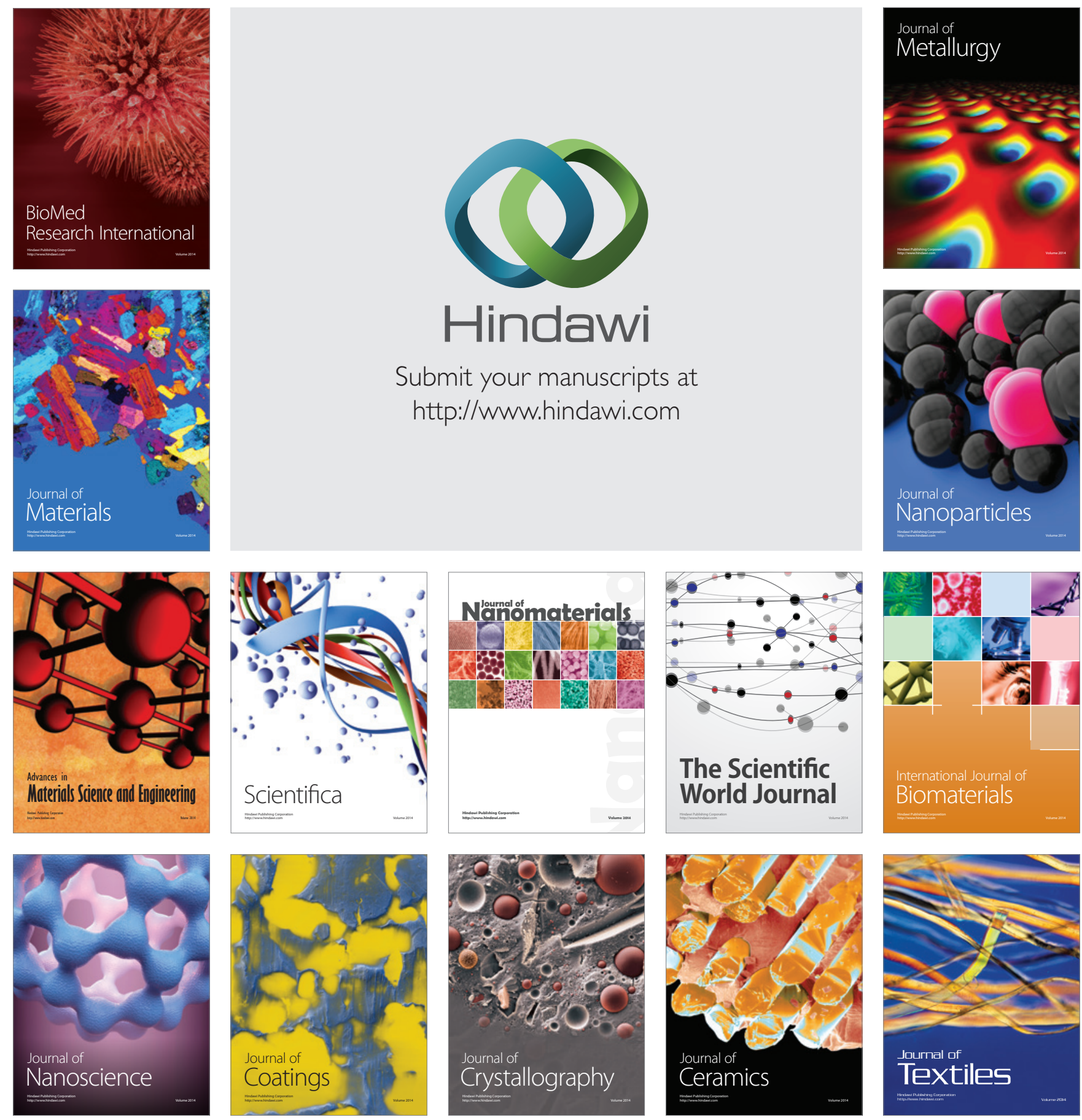